\title{
STUCK IN A RUT OR MERELY WITHIN THE LINES? INDIANA STATE CONSTITUTIONAL LAW SUMMARIES-2017-2018
}

\author{
SCOTT CHINN* \\ DANIEL E. PULLIAM ${ }^{* *}$ \\ ELIZABETH M. LITTLE***
}

\section{INTRODUCTION ${ }^{1}$}

The developments in Indiana constitutional law were minimal. Challenges to zoning exceptions based on the right to religion, criminal trespass convictions based on the freedom of speech, and the Indiana Tort Claims Act's protection of charter schools based on equal privileges and immunities principles all failed rather definitively. An Indiana Supreme Court decision under Article 1, Section 11 , found that a warrant to search a home may justify the use of flash-bang grenades in the execution of the search of that home. And a class action challenge to a county's system of providing public defenders to indigent criminal defendants failed because such claims were better suited for relief under the criminal trial procedures. Litigants were successful in striking down a law passed by the General Assembly that exempted rental housing fees for Bloomington and Lafayette - but no other jurisdictions - and in establishing a compensable taking with the elimination of an access road opening.

The successful challenges to special laws exempting individual municipalities and the removal of access roads rested on established precedent. But untested theories of constitutional law were readily rejected by the appellate courts as

* Scott Chinn is a partner at Faegre Baker Daniels LLP practicing public sector law and litigation. B.A., 1991, Indiana University; J.D., 1994, magna cum laude, Indiana University Robert H. McKinney School of Law. He is an adjunct professor at the McKinney School where he teaches Indiana Constitutional Law. Former Editor-in-Chief of the Indiana International and Comparative Law Review. He clerked for Judge David F. Hamilton, then District Judge, U.S. District Court, Southern District of Indiana.

** Daniel Pulliam is an associate in the business litigation group at Faegre Baker Daniels LLP. B.A., 2004, cum laude, Butler University, Indianapolis; J.D., 2010, magna cum laude, Indiana University Robert H. McKinney School of Law. He is also a former Editor-in-Chief of the Indiana Law Review and The Butler Collegian and a former law clerk for Judge John Daniel Tinder on the United States Court of Appeals for the Seventh Circuit.

*** Elizabeth Little is an associate in the finance and restructuring group at Faegre Baker Daniels LLP. B.A., 2011, Indiana University-Purdue University of Indianapolis; J.D., 2016, summa cum laude, Indiana University Robert H. McKinney School of Law. She is a former Executive Notes Editor of the Indiana Law Review.

1. The authors thank Brad Boswell, student at Indiana University Robert H. McKinney School of Law, for his invaluable assistance in gathering the materials for this article. The authors also thank Kristina Tinsley, student at Indiana University Robert H. McKinney School of Law and legal administrative assistant at Faegre Baker Daniels LLP, for her invaluable assistance in compiling the citations for this article. 
attempts to over-extend the power of the Indiana Constitution. For example, a summer youth camp's religious rights were not implicated because the Court refused to recognize that the local government zoning decision to grant a special exception to a large-scale dairy farm enabled the alleged harm to the camp. And a criminal defendant's claim that his refusal to leave a prosecutor's office when he challenged old tickets constituted free speech failed because his statements focused on himself and his tickets' dismissal. The lack of significant developments in Indiana Constitutional law during the survey period is consistent with what appears to be a trend in recent years.

The areas substantively addressed by Indiana's appellate courts increased to the median number as measured by the last five years. ${ }^{2}$ Substantive decisions in the areas of government searches and double jeopardy continue to issue regularly, but litigants saw little success in challenging laws as a violation of the ex post facto clause, unlike prior years, and generally no success in other areas addressing privileges and immunities, freedom of religion, and the right to a remedy.

\section{RIGHT TO WORSHIP AND FREEDOM OF RELIGION}

In House of Prayer Ministries, Inc. v. Rush County Board of Zoning Appeals, ${ }^{3}$ the Court of Appeals ${ }^{4}$ found no violation of a religious summer youth camp operator's religious rights under the Religious Land Use and Institutionalized Persons $\mathrm{Act}^{5}$ ("RLUIPA"), Indiana's Religious Freedom Restoration $\mathrm{Act}^{6}$ ("RFRA"), or Article 1, Sections 2 and 3 as a result of the zoning board's decision to grant a special exception to a dairy farm to construct and operate a concentrated animal feeding operation ("CAFO") one-half mile from the camp." Among other arguments, ${ }^{8}$ the camp operator argued that the zoning board violated its religious rights. ${ }^{9}$

2. Eighteen topics were addressed in 2014, Jon Laramore \& Daniel E. Pulliam, Indiana Constitutional Developments: Small Steps, 47 IND. L. REV. 1015, 1042 (2014); ten were addressed in 2015, Jon Laramore \& Daniel E. Pulliam, Developments in Indiana Constitutional Law: A New Equal Privileges Wrinkle, 48 IND. L. REv. 1223, 1240 (2015); fourteen were addressed in 2016, Scott Chinn \& Daniel E. Pulliam, Minimalist Developments in Indiana Constitutional Law-Equal Privileges Progresses Slowly, 49 IND. L. REV. 1004, 1021 (2016); twelve topics covered in 2017, Scott Chinn \& Daniel E. Pulliam, Emerging Federal Reliance-Continued State Constitutional Minimalism: Indiana State Constitutional Law Summaries-2015-2016, 50 IND. L. REV. 1216, 1238 (2017); and fourteen were addressed in 2018. See infra §§ I-XII.

3. 91 N.E.3d 1053 (Ind. Ct. App. 2018).

4. Unless otherwise noted, "Court of Appeals" and "Supreme Court" refer to the Indiana Court of Appeals and Indiana Supreme Court.

5. 42 U.S.C. $\S \S 2000 \mathrm{cc}$ to $2000 \mathrm{cc}-5$.

6. IND. CODE $\S \S 34-13-9-1$ to -11 .

7. House of Prayer Ministries, 91 N.E.3d at 1053.

8. This case has two constitutional issues. The other constitutional issue is addressed in section IV.

9. House of Prayer Ministries, 91 N.E.3d at 1063. 
The court first found RLUIPA inapplicable to the camp operator because RLUIPA only "applies to land use regulations imposed by a government directly on religious groups." ${ }^{\prime 0}$ Because the land regulated by the special exception was owned solely by the dairy farm, and not the camp operator, the Court found that the camp operator could not rely on RLUIPA. ${ }^{11}$ The plain language of the statute regulates land use regulations that limit or restrict land in which the claimant has a property interest. ${ }^{12}$ The court rejected the camp operator's argument that RLUIPA should apply to "any land that is affected by a regulation, even if the regulation is specifically directed to land in which the claimant has no interest" because the plain language of the statute is not ambiguous. ${ }^{13}$

The court next found unconvincing the camp operator's argument that RFRA prohibits the zoning board's grant of a special exception. ${ }^{14}$ "Indiana's RFRA prohibits 'a governmental entity' from 'substantially burden[ing] a person's exercise of religion, even if the burden results from a rule of general applicability." "15 The camp operator asserted that the special exception granted by the zoning board substantially burdened the camp's exercise of religion by "imperiling the health of the children" at the camp. ${ }^{16}$ The court recognized the possible harm the proposed CAFO could pose to the health of attendees which could result in fewer attendees at the camp, which then could "adversely affect" the camp operator's religious ministry efforts. ${ }^{17}$ However, the court found that the zoning board's decision was supported by substantial evidence. ${ }^{18}$ The zoning board, as the fact finder, found that the camp would not be substantially burdened because of the mitigation efforts the CAFO operator had in place. ${ }^{19}$

Finally, the court rejected the camp operator's argument that the zoning board's grant of a special exception "materially burdens" the camp operator's religious rights under Article 1, Sections 2 and 3 of the Indiana Constitution. ${ }^{20}$ "A [state constitutional] right is impermissibly alienated when the State materially burdens one of the core values which it embodies." ${ }^{21}$ For the reasons stated above regarding the zoning board's finding of no substantial burden on the camp operator, the court likewise found no evidence that the zoning board's decision would materially burden the camp operator's religious rights under Article 1, Sections 2 and $3 .^{22}$

10. Id.

11. Id.

12. Id.

13. Id. (emphasis in original).

14. Id. at 1064 .

15. Id. (internal citations omitted).

16. Id.

17. Id. at 1065 .

18. Id.

19. Id.

20. Id.

21. Id. (internal citations omitted).

22. Id. 


\section{FREEDOM OF THOUGHT AND SPEECH}

In McBride v. State, ${ }^{23}$ the Court of Appeals affirmed a criminal trespass conviction finding it did not violate Article 1, Section 9. The criminal trespass conviction arises out of an incident at the prosecutor's office where the defendant refused to leave until someone dismissed his old tickets. ${ }^{24}$ When asked to leave, the defendant maintained that he had a right to remain because it was a public office. $^{25}$ After refusing to leave, the defendant was arrested, charged, and convicted with criminal trespass. ${ }^{26}$ On appeal, the defendant sought reversal of his conviction claiming that it restricted his non-abusive expressive activity. ${ }^{27}$

Indiana courts evaluate free-speech violations of the Indiana Constitution "under a different standard than claims based on the First Amendment of the U.S. Constitution," using a two-step inquiry: (1) "a reviewing court must determine whether state action has restricted a claimant's expressive activity" and (2) "if it has, the court must decide whether the restricted activity constituted an 'abuse' of the right to speak." ${ }^{28}$ Regarding the first step, the Court found that the defendant's arrest restricted his expressive activity. ${ }^{29}$

Once the right to speak clause is implicated, the claimant "retains the burden of proving that the State could not reasonably conclude that the restricted expression was an 'abuse." ${ }^{\prime 30}$ One way for a claimant to try to meet this burden is to show that his expressive activity was political. ${ }^{31}$ If political, the burden shifts to the state to show that the restriction of such expressive activity did not "materially burden[] the claimant's opportunity to engage in political expression." ${ }^{\prime 2}$ If not political, or ambiguous as to whether the expression is political, "a reviewing court should find that the claimant has not established that it was political and should evaluate the constitutionality of any state-imposed restriction of the expression under standard rationality review." ${ }^{\prime 33}$ Because the defendant's statements focused at least in part on himself and the dismissal of his tickets, the Court found the statements ambiguous as to whether they were

23. 94 N.E.3d 703 (Ind. Ct. App. 2018).

24. Id. at 705-06.

25. Id. at 707 .

26. The criminal trespass statute makes a Class A misdemeanor, "[a] person who . . . not having a contractual interest in the property, knowingly or intentionally refuses to leave the real property of another person after having been asked to leave by the other person or that person's agent." IND. CODE $§ 35-43-2-2$.

27. McBride, 94 N.E.3d at 708.

28. Id. at 710 (quoting State v. Econ. Freedom Fund, 959 N.E.2d 794, 804-05 (Ind. 2011) (additional internal citations omitted)).

29. Id. at 711 .

30. Id. at 710 (internal citations omitted).

31. Id. at 711 .

32. Id.

33. Id. 
political and accordingly evaluated the restriction under a rational review standard. $^{34}$

Applying rationality review, the court examined whether the restricted activity constituted an abuse of the right to speak. "Rationality inquiry under $\S 9$ has historically been centered on whether the impingement created by the statute is outweighed by the public health, welfare, and safety served." 36 The court found the defendant's refusal to leave the prosecutor's office and demands to have his old tickets dismissed disrupted the prosecutor's office and made it difficult for employees to complete their work. ${ }^{37}$ Under these circumstances, the Court found that "the State could have reasonably determined that the defendant's conduct constituted an abuse of his right to speak[,]" and accordingly found no violation of Article 1, Section 9. ${ }^{38}$

\section{TAKINGS CLAUSE}

In Coutar Remainder I, LLC v. State, ${ }^{39}$ the Court of Appeals found the State's elimination of an opening to an access road abutting private property was a compensable taking. The State initiated condemnation proceedings to take property for the development of an interstate. ${ }^{40}$ The condemned property included an access road and access point from the subject land to a bordering state road. ${ }^{41}$ The property owners asserted that such taking would eliminate access to the property, resulting in the closure of the gas station and convenience store on the land. ${ }^{42}$ Because the property owners' deed specifically provided for the access point to the state road, they asserted that such closure of the access road is a compensable taking. ${ }^{43}$ The State moved for summary judgment on this issue, arguing that the closure of the access road and rerouting a half mile away was not a compensable taking because it simply created a different route to the property. ${ }^{44}$ The trial court agreed with the State and entered summary judgment in favor of the State. ${ }^{45}$ The Court of Appeals reversed the trial court and ordered a trial to determine the compensation owed to the property owners arising from the State's elimination of access to a state road. ${ }^{46}$

The court applies a two-part test in takings cases: (1) whether a taking has

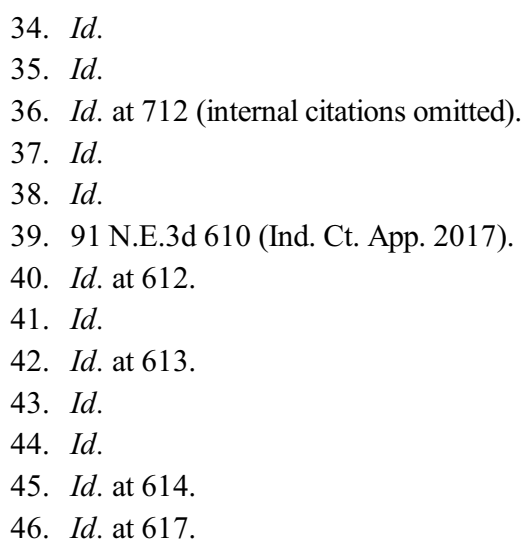


occurred, and (2) the amount of damages warranted. ${ }^{47}$ To determine whether a taking has occurred, the court must determine whether the property owner has a "property interest in the property." 48 Because "the property owner's deed expressly provides for the right of access that is now being taken," the court found that the elimination of such access point "constitutes a compensable interest in land." ${ }^{49}$ The court rejected the State's argument that the property owner "only has a property right of ingress and egress to [the access road] and not [the state road]," noting that the Supreme Court has stated that "an abutting property owner has an easement of ingress and egress in a public highway and this constitutes a property right which cannot be substantially or materially interfered with or taken away without due compensation." ${ }^{50}$

"The fact that the State may provide an alternate means of access to and from the [property] does not obviate the fact that the opening in the access control line is a covenant running with the land, and the State's elimination of the opening is a compensable taking." ${ }^{51}$ Having found that a taking occurred, the Court of Appeals held the property owner was entitled to a trial on the amount of damages for the taking. ${ }^{52}$

\section{PRIVILEGES AND IMMUNITIES}

In Flanner House of Indianapolis, Inc. v. Flanner House Elementary School, Inc. ${ }^{53}$ the Court of Appeals found that application of the Indiana Tort Claims Act to charter schools did not violate the equal privileges and immunities clause under Article 1, Section 23. ${ }^{54}$ This matter relates to a dispute between two Indiana nonprofits regarding breach of contract, negligence, and fraud claims arising from a lease contract between a charter school and its landlord. ${ }^{55}$ Among other arguments, the landlord argued that application of the notice and governmental immunity provisions of the Indiana Tort Claims Act (the "Act") to organizers of charter schools (in addition to the schools) violates the equal privileges and immunities clause under Article 1, Section 23. ${ }^{56}$

In determining a statute's validity under Article 1, Section 23, Indiana courts apply a two-part test: "(1) the disparate treatment accorded by the legislation must

47. Id. at 614 .

48. Id. at 615 .

49. Id.

50. Id.

51. Id. at 616-17.

52. Id. at 617 .

53. 88 N.E.3d 242 (Ind. Ct. App. 2018).

54. This case also briefly addresses the Open Courts Clause of Article I, $\S 12$. Rather curtly, the Court decided that granting a charter school immunity was a rational means to achieve the legitimate legislative goal of protecting the public treasury from the same monetary liability that private entities and persons must endure.

55. Id. at 244 .

56. Id. at 249 . 
be reasonably related to inherent characteristics that distinguish the unequally treated classes, and 2) the preferential treatment must be uniformly applicable and equally available to all persons similarly situated." 57

As to part one, the landlord asserted that charter schools, private schools, and nonprofit businesses were the disparately treated classes, and application of the Act to charter schools and their organizers was unfair. ${ }^{58}$ The Court of Appeals rejected this argument, finding that the unique and inherent characteristics of charter schools and their organizers (who are included in the classification of charter schools) warrant distinguishable treatment from private schools and other nonprofit businesses. ${ }^{59}$ Charter schools are characterized as public schools, operate pursuant to a charter agreement, and are subject to stringent laws and government oversight. ${ }^{60}$

By extending the liability protections of the Act to charter schools, the legislature furthered its overall purpose of providing innovative programs for public school students and educators while preserving the public treasury and protecting public employees acting within the scope of their employment. We conclude the disparate application of the Act in this instance constitutes treatment that is reasonably related to the inherent characteristics that differentiate charter schools from private schools and other nonprofit corporations. ${ }^{61}$

As to part two, the landlord conceded that the Act is "uniformly applicable and equally available to all charter schools" and failed to meet its burden of negating "every conceivable basis which might support the classification." Accordingly, the Court of Appeals held that application of the notice and governmental immunity provisions of the Act to the charter school and its organizers did not violate Article 1, Section $23 .^{63}$

In House of Prayer Ministries, ${ }^{64}$ the Court of Appeals found that a zoning board's application of an ordinance requiring a setback for a concentrated animal feeding operation ("CAFO") from a school and not a youth camp did not violate the Equal Privileges and Immunities Clause under Article 1, Section 23. ${ }^{65}$ The operator of a religious summer youth camp appealed from the trial court's denial of its petition for judicial review from the zoning board's decision to grant a special exception to a dairy farm to construct and operate a CAFO one-half mile

57. Id. at 250 .

58. Id.

59. Id.

60. Id.

61. Id. at 251 .

62. $I d$.

63. Id. at 251-52.

64. House of Prayer Ministries, Inc. v. Rush Cty. Bd. of Zoning Appeals, 91 N.E.3d 1053

(Ind. Ct. App. 2018).

65. Id. at 1065. 
from the camp. ${ }^{66}$ Among other arguments,${ }^{67}$ the camp operator argued that the zoning board incorrectly allowed the CAFO to be constructed only one-half mile from the camp when a zoning ordinance requires construction of a CAFO to be at least one mile from a school. ${ }^{68}$ The camp operator asserted that the zoning board violated the Equal Privileges and Immunities Clause under Article 1, Section 23 through its application of the "onemile setback to 'other types of schools, but not youth camps." The camp claimed this was disparate treatment that was not reasonably related to inherent characteristics that distinguish the unequally treated classes. ${ }^{69}$

In applying the two-part test, the court first found that the strict regulation and mandatory attendance requirements of schools distinguishes schools from largely unregulated, voluntary summer youth camps. ${ }^{70}$ And the disparate treatment of schools from youth camps is reasonably related to such distinguishing characteristics. ${ }^{71}$ As to the second part of the test, "[t]he one-mile setback requirement for schools and one-half mile setback for other entities treats all schools the same and it treats all summer camps the same." 72 Accordingly, the Court found the zoning ordinance to be "uniformly applicable and equally available to all persons similarly situated," and not in violation of Article 1, Section $23 .^{73}$

\section{No SPECIAL LAWS (ARTICLE 4, § 22)}

In City of Hammond v. Herman \& Kittle Properties, Inc. ${ }^{74}$ the Court of Appeals reversed a trial court decision that found a 2015 statute granting an exemption to a rental housing fee restriction only applicable to two Indiana cities was not unconstitutional special legislation under Article 4, Sections 22 and 23..$^{75}$ This matter arises out of a rental housing inspection program the City of Hammond created in 1961 that required annual registration and registration fees for rental housing. ${ }^{76}$ In 2014, the Indiana General Assembly enacted a statute that

66. Id. at 1056 .

67. This case has two constitutional issues. The other constitutional issue is addressed in section I.

68. Id. at 1061.

69. Id.

70. Id.

71. Id.

72. Id.

73. Id. (internal citations omitted).

74. 95 N.E.3d 116 (Ind. Ct. App. 2018). The Indiana Supreme Court granted transfer (outside this survey period), holding that while the fee exemption within the statute governing rental housing fees violates Article 4, Section 23, the fee restriction remains in force because a nonseverability clause was absent from the statute. City of Hammond v. Herman \& Kittle Properties, 119 N.E.3d 70, 89 (Ind. 2019). This decision will be addressed in the next survey article.

75. Id. at 144 .

76. Id. at 119 . 
restricted fees rental registration programs could impose. ${ }^{77}$ Based on the 2014 statute, a rental property company disputed amounts Hammond asserted it owed. ${ }^{78}$ However, the 2014 statute included an exemption for rental registration programs that were created prior to July $1,1984 .{ }^{79}$ Because Hammond's program was enacted in 1961, Hammond claimed it was exempt from the 2014 statute. ${ }^{80}$ While this action was pending, the Indiana General Assembly enacted a statute that further amended the 2014 statute's definition of "rental registration or inspection program" that specifically disqualified Hammond's program from an exemption. ${ }^{81}$ Hammond claimed this 2015 amendment was special legislation in violation of Sections 22 and $23 .{ }^{82}$ On competing motions for summary judgment, the trial court found that Hammond qualified for the fee exemption under the 2014 statute, but that the 2015 exemption-which is a special law-did not violate the Indiana Constitution. ${ }^{83}$

As a preliminary matter, the Court of Appeals found that Hammond had standing to bring this challenge under Sections 22 and 23 because it would sustain a direct injury-including annual losses of hundreds of thousands of dollars - if the 2015 statute was upheld. ${ }^{84}$

Sections 22 and 23 prohibit the enactment of local or special laws, and require general laws, relating to certain subjects. ${ }^{85}$ To begin its constitutional analysis, the Court of Appeals determined whether the 2015 statute was a special or general law. "A statute is general if it applies to all persons or places of a specified class throughout the state, and a statute is special if it pertains to and affects a particular case, person, place, or thing, as opposed to the general public. ${ }^{\prime 87}$ If general, the law must be applied generally. ${ }^{88}$ If special, the law must be constitutionally permissible. ${ }^{89}$ The rental property company conceded that the 2015 statute was a special law but asserted that it was constitutionally permissible. $^{90}$

Section 22 prohibits special legislation that relates to one of the sixteen enumerated subjects, including fees or salaries. ${ }^{91}$ The rental company argued, and the trial court agreed, that the fees referenced in Section 22 relate only to fees

77. Id.
78. Id.
79. Id.
80. Id.
81. Id. at 120.
82. Id.
83. Id.
84. Id.
85. Id. at 131.
86. Id. at 130.
87. Id. at 135 (internal quotations omitted).
88. Id.
89. Id.
90. Id.
91. Id. 
"used to directly compensate [constitutional] public officials for their services as they were in 1851 when Section 22 was written." ${ }^{92}$ However, the Court of Appeals interpreted Section 22 more broadly, finding "that when the State sets a fee - any fee - it should apply uniformly. ${ }^{\circ 93}$ Further, the Court of Appeals found that the fee restriction in the 2015 statute at issue here applied to the salaries of those operating the programs, which is the same as has been historically applied. ${ }^{94}$ The statute "relates to fees for rental registration programs and allows Bloomington and West Lafayette and only Bloomington and West Lafayette to charge a fee different than all other political subdivisions in the State. ${ }^{95}$ [The statute] therefore runs afoul of Article 4, Section 22, which prohibits special laws relating to fees or salaries." ${ }^{96}$

Even though the Court of Appeals found that the 2015 statute was unconstitutional under Section 22, the Court of Appeals still completed a constitutional analysis of the statute under Section 23 and again found the 2015 statute unconstitutional..$^{97}$ The Court of Appeals provided a thorough account of the history of the Indiana Constitution's treatment of special legislation and of the prior seminal case in the modern era, Municipal City of South Bend v. Kimsey. ${ }^{98}$

Even if a statute does not relate to one of the enumerated subjects in Section 22 , Section 23 requires a law to be made general where possible. ${ }^{99}$ Because the rental property company conceded that the 2015 statute was a special law, the Court of Appeals considered whether there were certain traits and reasons to treat the affected area differently. ${ }^{100}$

The Court of Appeals found that the legislative history of the 2015 statute details how it could be applied generally. The statute initially was applied generally, but then, through a series of amendments, ultimately benefitted only Bloomington and West Lafayette. ${ }^{101}$ The Court of Appeals rejected the rental property company's argument that Bloomington and West Lafayette present unique traits (home to the largest college campuses in the state with a high percentage of rental housing to young, unsophisticated renters) to justify the differential treatment. ${ }^{102}$ And instead found these unique traits "to have been hand-picked post hoc to justify the differential treatment imposed by the statute." 103 Accordingly, the Court of Appeals found the 2015 Statute

92. Id. at 136 (emphasis in original).

93. Id.

94. Id.

95. Id.

96. Id. at 138 (emphasis in original).

97. Id.

98. 781 N.E.2d 683 (Ind. 2003).

99. City of Hammond, 95 N.E.3d at 138.

100. Id. at 138-39.

101. Id. at 140 .

102. Id.

103. Id. at 143 . 
unconstitutional under Section 23 as well. ${ }^{104}$ As a result, the Court of Appeals struck down the entire statute governing rental housing fees, rather than only the exemption for Bloomington and West Lafayette, because the legislative history showed that the General Assembly "specifically avoided" applying the rental housing fee cap on Bloomington and West Lafayette. ${ }^{105}$

\section{SEARCH AND SEIZURE}

In Watkins v. State, ${ }^{106}$ the Indiana Supreme Court reversed a Court of Appeals decision that deemed a military-style entry into a home based on a confidential tip an unreasonable search and seizure under Article 1, Section 11. ${ }^{107}$ Law enforcement obtained a search warrant and decided to use that search warrant to justify sending twelve SWAT officers into the home after conducting surveillance of the home. ${ }^{108}$ After an officer broke the door down with a battering ram, another officer tossed a flash-bang grenade into a room with a nine-month old boy in a playpen under a blanket. ${ }^{109}$ Inside the home, the officers found crack cocaine, marijuana, hydrocodone pills, other drugs, and a .40 caliber handgun. ${ }^{110} \mathrm{~A}$ majority of the Court of Appeals found the search unreasonable under the "Litchfield test" which examines reasonableness under the totality of the circumstances. ${ }^{111}$

On transfer, the Supreme Court re-established the "well-suited" nature of the Litchfield test as "applied hundreds of times in our courts." 12 The State had argued that Litchfield did not apply to cases involving search warrant executions. ${ }^{113}$ Instead, the state argued that search warrant executions were only unreasonable under the Indiana Constitution, if "no reasonable officer" would execute a search that way. But the Court held, again, that Litchfield applied to all government searches and to the method of their execution. ${ }^{114}$ It was unnecessary to exclude its test to search warrant executions because the "totality-of-thecircumstances test" was a faithful standard under the Indiana Constitution in all contexts. ${ }^{115}$

Yet, contrary to the Court of Appeals panel majority, the Supreme Court unanimously found the search reasonable. ${ }^{116}$ Although the Court declined the

\footnotetext{
104. Id. at 144 .

105. Id.

106. 85 N.E.3d 597 (Ind. 2017).

107. Id. at 604 .

108. Id. at 598 .

109. Id. at 598-99.

110. Id. at 599.

111. Id.

112. Id. at 600 .

113. Id.

114. Id.

115. Id.

116. Id. at 603 .
} 
State's request to change the standard when a warrant is involved, the fact law enforcement obtained a warrant meant that the degree of police suspicion was high. ${ }^{117}$ The confidential informant had been deemed reliable, traffic to and from the house was consistent with active drug dealing, and police found a small plastic bag behind the home. ${ }^{118}$ The court found the degree of intrusion reasonable because of actions law enforcement took to minimize the impact of the flash-bang grenade by peaking around the door's corner and setting it off six inches inside of the door. ${ }^{119}$ Law enforcement needs were justified by the after-the-fact discovery of the gun in the home and the suspect's criminal history. ${ }^{120}$ Although the search was certainly intrusive, the law enforcement needs and the degree of suspicion overrode that factor. ${ }^{121}$

The Court also refused to apply a line of cases from the Seventh Circuit that found that flash-bang grenade tactics in homes went beyond the bounds of reasonableness because those decisions rested on the Fourth Amendment, not Article 1, Section 11 of the Indiana Constitution. ${ }^{122}$ The tests are distinct; the Seventh Circuit did not apply a totality-of-the circumstances test. ${ }^{123}$

The Court concluded by noting that using flash-bang grenades should be the exception because the "extraordinary degree of intrusion will in many cases make a search constitutionally unreasonable." ${ }^{24}$ The Court also expressed concern that law enforcement used the flash-bang grenade in a room that only had a ninemonth old child. ${ }^{125}$ Yet despite these expressions of apprehension, the Court's analysis does not instruct on what circumstances would constrain use of a flashbang grenade or similar force in the execution of a valid search warrant, even those involving homes where degree of intrusion is high. The federal constitutional right to have firearms in one's home ${ }^{126}$ means that law enforcement can always cite officer safety when entering a home, and although the Court refused to apply the "no reasonable officer" standard to cases involving warrants issued on probable cause, the Court was willing to apply a high-degree of criminal suspicion on the basis of the warrant's issuance regardless of the underlying facts before the trial court. ${ }^{127}$ Put otherwise, if law enforcement obtained a search warrant, it is difficult to see how the Indiana Constitution will prevent law enforcement from using flash-bang grenades, and other similar force, when entering a home on the basis of that search warrant.

117. Id. at 601 .

118. Id.

119. Id. at 601-02.

120. Id. at 602 .

121. Id.

122. Id.

123. Id.

124. Id. at 603 .

125. Id.

126. McDonald v. City of Chi., 561 U.S. 742, 742 (2010).

127. Watkins, 85 N.E.3d at 604. 
In McGrath v. State, ${ }^{128}$ the Indiana Supreme Court found that in the totality of the circumstances, probable cause supported two search warrants based on a partially corroborated anonymous tip of potential marijuana growing in a home. ${ }^{129}$ The anonymous tip described the house, the first names of its occupants, and described a bright light from a window and the smell of marijuana. ${ }^{130}$ An officer investigated the home and observed covered windows and two air-conditioning units on the second floor separate from the home's central air system. ${ }^{131} \mathrm{He}$ did not however smell the marijuana. ${ }^{132}$ Based on this information, the officer obtained a search warrant for a thermal imaging camera mounted on a drone used to measure heat consistent with an indoor marijuana-growing operation. ${ }^{133}$ Based on the camera's confirmation of abnormal amounts of heat emanating from the home, the officer obtained a second warrant to search the premises. ${ }^{134}$ The search revealed an extensive marijuana growing operation. ${ }^{135}$

The Court of Appeals had ordered the evidence obtained from the search suppressed because observation of air conditioning units and lighting coming from windows was not sufficient to establish probable cause of criminal activity. ${ }^{136}$ But the Supreme Court reversed. The covered windows, the air conditioning systems, and the partial confirmation of the anonymous tip supported probable cause of criminal activity. ${ }^{137}$ The facts, viewed discretely, seemed innocent. ${ }^{138}$ But when viewed together-that is, the collective nature of the facts and their context - the officer had sufficient evidence indicative of a marijuana growing operation. ${ }^{139}$

In Conn v. State, ${ }^{140}$ the Court of Appeals ordered evidence found by law enforcement after climbing over a gate to a private club suppressed. ${ }^{141}$ The incident began with a group of friends shooting firearms at a pizza box at the private club. ${ }^{142}$ A neighbor heard the gunshots, which she often heard, but never that late at night. ${ }^{143}$ An hour later, she called the police and told them that it was possible animals were being killed illegally. ${ }^{144}$ Three officers encountered a driver

128. 95 N.E.3d 522 (Ind. 2018).

129. Id. at 525 .

130. Id.

131. Id.

132. Id.

133. Id.

134. Id. at 526.

135. Id.

136. Id.

137. Id. at 528 .

138. Id. at 529 .

139. Id.

140. 89 N.E.3d 1093 (Ind. Ct. App. 2017).

141. Id. at 1095 .

142. Id. at 1096.

143. Id.

144. Id. 
behind the gate, who told the officers that he was waiting for someone to unlock the gate. ${ }^{145}$ One officer stayed with the driver while the others climbed over the gate. ${ }^{146}$ The officers, once inside, saw someone-who was later determined to be the defendant — walk behind the club's building. ${ }^{147}$ Once the officers approached the defendant, he claimed to have been urinating, but then admitted to having hidden a firearm behind the building. ${ }^{148}$ Upon inspection, the officers found a handgun, ammunition, and a purse containing a glass pipe, a pen modified into a straw, and baggies of methamphetamine. ${ }^{149}$

The Court of Appeals found the degree of suspicion low under the Litchfield test. ${ }^{150}$ The officers conceded at trial that they knew it was not against the law to shoot guns at the club and none of the officers saw evidence of criminal activity. ${ }^{151}$ The degree of intrusion, given the locked gate, was high. ${ }^{152}$ The officers could have obtained a warrant or waited for the gate to be unlocked. ${ }^{153}$ When an Indiana citizen puts in place a mechanism to keep others out, ignoring those "obstructions constitutes highly intrusive conduct by law enforcement."154 Law enforcement needs were low. ${ }^{155}$ The shooting was not seen to be irresponsible or otherwise dangerous. ${ }^{156}$ Gunfire at the club was "not uncommon." 157 Given these factors, the State failed to meet its burden that the officers acted reasonably and ordered the evidence of the methamphetamine and paraphernalia suppressed. ${ }^{158}$

Chief Judge Vaidik dissented on the basis that the defendant lacked standing to challenge the evidence under Article 1, Section 11 of the Indiana Constitution. ${ }^{159}$ The officers' conduct was constitutionally suspect, but the defendant failed to show that he had a property interest in the club. ${ }^{160}$ He was not an owner, member, or even an invited guest on the property. ${ }^{161} \mathrm{He}$ also failed to assert any interest in the methamphetamine or paraphernalia. ${ }^{162}$

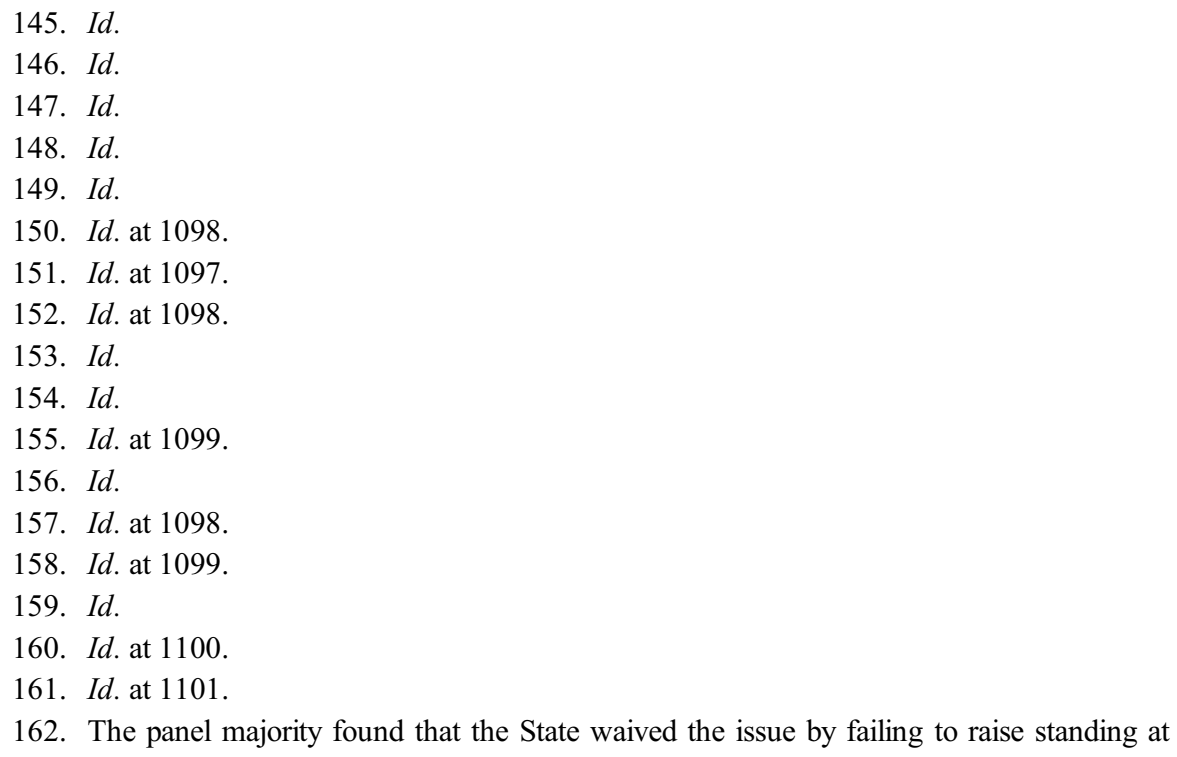


In Wright v. State, ${ }^{163}$ the Court of Appeals refused to apply the federal Fourth Amendment attenuation doctrine in finding the results of an unconstitutional search suppressed. ${ }^{164}$ Law enforcement had indisputably searched and seized the defendant's computer for child pornography in violation of Section $11 .{ }^{165}$ Without a warrant or consent, law enforcement told the defendant that they could "freeze the scene" by removing the home's residents on a cold winter day or simply take the computers and return them as soon as possible. ${ }^{166}$ The defendant agreed to the computers' removal, which led to the discovery of child pornography and then a confession by the defendant to law enforcement that he had participated in child molestation. ${ }^{167}$ This search and seizure violated Section 11, but the State maintained that the later statements by the defendant, admitting to molesting children and recording it onto the computers, were sufficiently attenuated from the illegal seizure of the computers. ${ }^{168}$ The Court found that, consistent with a long line of appellate decisions, the attenuation doctrine did not apply to Section 11 claims. ${ }^{169}$ The government did not dispute that the defendant's incriminating statements stemmed "directly" from the unconstitutional search and seizure of the computers. ${ }^{170}$ The statements were thus unlawfully admitted as evidence against the defendant and his conviction was reversed. ${ }^{171}$

In Randall v. State, ${ }^{172}$ the Court of Appeals addressed the Litchfield factors in a case that did not arise in a criminal investigation. Mr. Randall's arrest stemmed from a "welfare check" after law enforcement observed him appearing slumped over in his car in a same-day surgery parking lot with the door open and the ignition off. ${ }^{173}$ The Court found that Litchfield's "degree of concern, suspicion, or knowledge that a violation has occurred" could be read in the context of an emergency aid exception. ${ }^{174}$ Here, the deputy's concern was high and although once Mr. Randall exited the vehicle that concern dissipated, it remained reasonable. ${ }^{175}$ Because of that "high concern" and the brief seizure's minimal intrusion on Mr. Randall, the court found the seizure permissible under Article 1, Section $11 .^{176}$

163. 92 N.E.3d 1127 (Ind. Ct. App. 2018).

164. Id. at 1133 .

165. Id. at 1129.

166. Id.

167. Id. at 1130 .

168. Id. at 1132 .

169. Id. at 1133 .

170. Id.

171. Id. The Indiana Supreme Court granted transfer (outside this survey period), holding that the attenuation doctrine can apply under the Indiana Constitution. Wright v. State, 108 N.E.3d 307, 311 (Ind. 2018). This decision will be addressed in the next survey article.

172. 101 N.E.3d 831 (Ind. Ct. App. 2018).

173. $I d$. at 835 .

174. $I d$. at 841 .

175. Id. at $841-42$.

176. Id. at 842 . 
In Baxter v. State, ${ }^{177}$ the Court of Appeals addressed whether a 911 call from a Mike's Carwash stating that "two black suspicious males" were on the property, not using the carwash, and appeared to be evading the business's security cameras justified police blocking the defendant's vehicle in while they checked for warrants. ${ }^{178}$ The warrant check came back negative, but when the officer approached the car, he smelled marijuana and received no response when he asked the car's occupant to exit the vehicle. ${ }^{179}$ This smell of marijuana, and the lack of a response, served as a sufficient degree of concern, suspicion, or knowledge that a violation had occurred to justify what the Court deemed a minor degree of intrusion and a strong need for law enforcement protection given the heavy tint of the windows and the officer's lack of knowledge regarding the number of the car's occupants. ${ }^{180}$

The Court analyzed the fact that Mr. Baxter was detained by law enforcement without any evidence of criminal activity in addressing his Fourth Amendment claim. ${ }^{181}$ There, the Court reasoned that blocking the car did not constitute a seizure under the Fourth Amendment because although he lacked the ability to drive away, the encounter lasted five minutes, there was no use of force, display of a weapon, or language or tone of voice suggesting that law enforcement accused Baxter of criminal activity. ${ }^{182}$ Baxter should have felt free to leave the scene by asking the officer to move his police vehicle. ${ }^{183}$

Once again, ${ }^{184}$ the Court of Appeals resolved defendants' claims under the Fourth Amendment and declined to address claims under the Indiana Constitution. In Sansbury v. State, ${ }^{185}$ the Court applied the Fourth Amendment doctrine governing warrantless inventory searches and found that because law enforcement actions "deviated greatly" from the department's policy, the evidence of handguns found in the car had to be suppressed. ${ }^{186}$ Similarly, in Wilson v. State ${ }^{187}$ the Court of Appeals held that a Terry ${ }^{188}$ stop lacked sufficient specific and articulable facts of reasonable suspicion of criminal activity under the Fourth Amendment and declined to address the Indiana constitutional

177. 103 N.E.3d 1180 (Ind. Ct. App. 2018).

178. Id. at 1183 .

179. Id.

180. Id. at 1191 .

181. Id. at 1188 .

182. Id. at 1189 .

183. Id. at 1190.

184. Scott Chinn \& Daniel E. Pulliam, Emerging Federal Reliance-Continued State Constitutional Minimalism: Indiana State Constitutional Law Summaries-2016-2017, 51 IND. L. REV. 993, 1006 (2018).

185. 96 N.E.3d 587 (Ind. Ct. App. 2017).

186. $I d$. at 593 .

187. 96 N.E.3d 655 (Ind. Ct. App. 2018).

188. Terry v. Ohio, 392 U.S. 1 (1968). 
issues. ${ }^{189}$ And in Marshall v. State, ${ }^{190}$ the Court of Appeals concluded that because it held that a traffic stop lacked a reasonable suspicion of criminal activity - the officer eyeballed the speed of Mr. Marshall's vehicle to conclude he was speeding - it need not address the claims under the Indiana Constitution.

The results in these cases are reasonable. Addressing a second basis for invalidating the results of the searches would seem to be an exercise in judicial inefficiency as the chance of these decisions being subject to federal review seems unlikely. ${ }^{191}$ But they are missed opportunities to show where the State test differs from the federal test and to develop an independent doctrine that may be used to both protect the rights of the citizens of Indiana and to provide law enforcement with further guidance. As noted in Marshall, the Indiana Constitution provides broader protection than the Federal Constitution, ${ }^{192}$ but that may not continue to be the case if the Courts are not separately analyzing the provisions.

\section{OPENNESS OF COURTS}

In State v. Lindauer ${ }^{193}$ the Court of Appeals reversed a trial court's dismissal of misdemeanor charges related to operating a vehicle while intoxicated and possession of marijuana because of delays in bringing his case to trial. ${ }^{194}$ The State charged Mr. Lindauer on April 6, 2016, but after multiple continuances, he filed a motion to dismiss under Indiana Rule of Criminal Procedure 4(C) on April 13, 2017. ${ }^{195}$ The Court of Appeals decision came down on the language of the $\mathrm{CCS}$ - "the official record of the trial court"-which indicated that Lindauer was granted several of the continuances, not the State. ${ }^{196}$ Therefore, because a defendant cannot habitually move to reset the preliminary hearing at which a trial date would be set, the trial court committed clear error in dismissing the charges. ${ }^{197}$

Judge Riley dissented because although the CCS was the trial court's official record, review of the proceedings' transcripts indicated a more nuanced picture

189. Wilson, 96 N.E.3d at 658 , n.9.

190. 105 N.E.3d 218 (Ind. Ct. App. 2018).

191. For example, in 2017, 6,315 petitions for certiorari were filed in 2017. See Caseloads: Supreme Court of the United States, 1878-2017, FED. JUD. CTR., https://www.fjc.gov/history/ courts/caseloads-supreme-court-united-states-1878-2017 [https://perma.cc/FY28-J89G]. The court routinely grants around eighty per term. See Supreme Court Procedure, SCOTUS BLOG, https://www.scotusblog.com/reference/educational-resources/supreme-court-procedure/ [https://perma.cc/CBW2-XN6X].

192. 105 N.E.3d 211 (Ind. Ct. App. 2018).

193. Id. at 216.

194. Id. at 213.

195. Id.

196. Id. at 215 .

197. Id. at 216 . 
showing both the State and Mr. Lindauer engaging in plea negotiations. ${ }^{198}$ The record showed that Mr. Lindauer objected in a timely manner to waiving his rights to a speedy trial. ${ }^{199}$

\section{RIGHTS OF THE ACCUSED AND VICTIMS}

In Leonard v. State, ${ }^{200}$ the Court of Appeals held that the trial court's admission of jail cell phone calls between a defendant charged with murder in the Richmond Hill explosion case and a jailhouse informant did not violate Article 1, Section 13's right to counsel. ${ }^{201}$ The Indiana Supreme Court has held that Indiana's protections go further than the federal Sixth Amendment right to counsel and guard against the government's coercive abilities. Once the government and defendant's adverse positions have solidified, the government cannot use its coercive forces to surveil the defendant because doing so would deny defendants their right to counsel. ${ }^{202}$ But here, law enforcement were investigating the murder suspect's jailhouse plot to murder a witness against him in the Richmond Hill case. ${ }^{203}$ Therefore, although the two crimes were related, the Richmond Hill murder suspect had no Article 1, Section 13 right to counsel against these potential charges. ${ }^{204}$ Holding otherwise would frustrate law enforcement interests in investigating additional crimes after a suspect is charged with one crime. ${ }^{205}$

In Alford v. Johnson County Commissioners,${ }^{206}$ the Indiana Court of Appeals held that the rights of indigent criminal defendants in Johnson County under Article 1, Section 13 are not infringed by the assignment of public defenders. ${ }^{207}$ The plaintiffs, a group of seven men charged with crimes in Johnson County and assigned public defenders, argued that the Johnson County public defender system "systematically" deprived indigent people of the right to counsel. ${ }^{208}$ But the complaint just alleged that the public defenders did not provide the plaintiffs with effective assistance of counsel, "an allegation of an individualized claim for relief, and not a claim of a systematic deprivation of constitutional rights." ${ }^{209}$ The Court found that such "individualized claims" are better suited for relief pursuant to criminal trial procedures. ${ }^{210}$ Therefore, the Court of Appeals affirmed the trial

198. Id. at 216-17.

199. Id. at 217.

200. 86 N.E.3d 406 (Ind. Ct. App. 2017).

201. Id. at 414 .

202. Jewell v. State, 957 N.E.2d 625, 628 (Ind. 2011).

203. Leonard, 86 N.E.3d at 408.

204. Id. at 413 .

205. Id.

206. 92 N.E.3d 653 (Ind. Ct. App. 2017).

207. $I d$. at 655 .

208. Id. at 659 .

209. Id. at 660 .

210. Id. 
court's dismissal of the claim for failure to state a claim upon which relief could be granted. ${ }^{211}$

In Wilson v. State, ${ }^{212}$ the Court of Appeals admonished the trial court for failing to understand the right of an individual to represent oneself. "This egregious lack of knowledge presents a serious risk to the rights of defendants and demands that we direct the trial court to case law regarding a criminal defendant's fundamental rights. We advise the trial court to review this case law in depth and without delay." ${ }^{213}$ The Court of Appeals then found that the defendant's appellate counsel provided ineffective assistance of counsel by failing to review the trial court transcripts for issues to appeal. ${ }^{214}$ The record on appeal in Indiana includes "all proceedings before the trial court, ${ }^{215}$ including pretrial hearings, and therefore, appellate counsel's failure to review those transcripts constituted ineffective assistance of counsel. ${ }^{216}$ Appellate counsel's deficient performance resulted in the failure to raise the issue of whether the defendant knowingly waived his right to counsel. ${ }^{217}$ The defendant suffered prejudice because not only did the trial court fail to advise the defendant of the risks of selfrepresentation, appellate counsel's failure to raise the issue likely missed an opportunity for the conviction's reversal. ${ }^{218}$

In State v. Bonds, ${ }^{219}$ the Court of Appeals held that the "clear language" of Article 1, Section 13 affords rights only to the accused. ${ }^{220}$ Neither the Indiana Constitution, nor the U.S. Constitution, affords any right to a jury trial to the State. ${ }^{221}$ The general principle - that both constitutions afford enumerated rights to protect the citizenry from over reach by the government - meant that even though Article 1, Section 13 did not mention the State, the State could not invoke the rights afforded under that provision. ${ }^{222}$

The fact that the State sought a jury in this case, pressing it to interlocutory appeal, suggests that in some cases, the State sees an advantage to having a jury decide facts over the Judge. ${ }^{223}$ Here, a Marion County trial judge denied the State's demand for a jury trial after the defendant, charged with two misdemeanor offenses waived her right to trial by jury, asking for a bench trial. ${ }^{224}$ After the deputy prosecutor informed the judge that the State did not waive a jury, the

211. Id. at 661 .

212. 94 N.E.3d 312 (Ind. Ct. App. 2018).

213. Id. at 320 .

214. Id. at 325 .

215. IND. APP. R. 2(L).

216. Wilson, 94 N.E.3d at 325.

217. Id. at 322 .

218. Id. at 324-25.

219. 94 N.E.3d 333 (Ind. Ct. App. 2018).

220. Id. at 336 .

221. Id.

222. Id.

223. See id.

224. Id. at 335 . 
Court reminded the deputy prosecutor that the defendant was just charged with misdemeanor charges (carrying a handgun without a license and possession of marijuana) and set the case for a bench trial. ${ }^{225}$ On appeal, the court noted that the State's claim that it somehow had a right to a jury trial ignored that constitutional rights "are specifically created by enumeration, not by silence."226

In Hudson v. State, ${ }^{227}$ the Court of Appeals reversed because the record revealed that the trial court failed to advise the defendant charged with misdemeanor battery of the consequences of failing to demand a jury trial or of the specific requirements for making such a demand. ${ }^{228}$ The public defender assigned to the defendant and the State signed an "off record request form" asking for a bench trial in the face of the defendant's complaints about his appointed counsel. ${ }^{229}$ Because the trial court never advised the defendant of the consequences of failing to demand a jury trial, he did not knowingly waive that right even in a misdemeanor case. ${ }^{230}$

\section{DOUBLE JEOPARDY}

In Edmonds v. State, ${ }^{231}$ the Indiana Supreme Court cautioned courts from deciding constitutional questions when an interpretation of the statute disposes of the issue. ${ }^{232}$ The Court addressed whether an Indiana statute allowed multiple felony convictions stemming from a single act of resisting law enforcement where the act of resisting resulted in a death and two serious bodily injuries. ${ }^{233}$ The Court noted that the Court of Appeals, in vacating the convictions, based its decision in constitutional double jeopardy prohibitions. ${ }^{234}$ But the Supreme Court reasserted the caution "against deciding cases on a constitutional basis where other options for disposing of the issue exist." ${ }^{235}$ Instead of deciding the case on double jeopardy grounds, the Court found that the Indiana Code section's language criminalized "a single instance of resisting law enforcement." 236 This "single harm to the peace and dignity of the State" may only result in a single felony, regardless of the amount of death and serious bodily injury that stems from the incident. ${ }^{237}$

225. Id

226. Id. n.2.

227. 109 N.E.3d 1061(Ind. Ct. App. 2018).

228. Id. at 1065 .

229. Id. at 1062 .

230. Id. at 1065 .

231. 100 N.E.3d 258 (Ind. 2018).

232. Id. at 262.

233. Id. at 261.

234. $I d$.

235. Id. at 262 .

236. Id. at 263.

237. Id. 
In Henson v. State, ${ }^{238}$ the Court of Appeals vacated a conviction for criminal recklessness because of the "reasonable possibility that the jury "latched on to exactly the same facts for" multiple felony battery convictions. ${ }^{239}$ The defendant had driven his car into a Speedway gas station's gasoline pumps, causing explosions and multiple injuries. ${ }^{240}$ The state charged the defendant with felonies for the injuries stemming from this incident. ${ }^{241}$ The State admitted error and the Court reversed two of the defendant's convictions. ${ }^{242}$

In Howell v. State, ${ }^{243}$ the Court of Appeals held that convictions for attempted robbery and criminal recklessness (a lesser included offense for attempted murder) violated Indiana double jeopardy principles under the "actual evidence" test because the evidence at trial did not establish both convictions by separate and distinct facts. ${ }^{244}$ Both convictions rested on the defendant's discharge of a firearm into a vehicle. ${ }^{245}$ At closing argument, the prosecutor told the jury that the two charges would be addressed "together." ${ }^{246}$ Because the violation could not be eliminated by reducing either conviction to a less serious form of the offense, the Court remanded with instructions to vacate the criminal recklessness conviction. ${ }^{247}$

In Taylor v. State, ${ }^{248}$ the Court of Appeals reversed two convictions for criminal confinement because the defendant's act of confining two individuals "was part and parcel of how" the defendant accomplished a robbery. ${ }^{249}$ The prosecutor presented no evidence of a significant length of confinement after the defendant completed the robbery. ${ }^{250}$ Forcing the home owners into a separate room, zip tying their wrists, and beating them up, was simply part of the robbery. ${ }^{251}$

\section{RIGHT TO BEAR ARMS}

In Wilder v. State, ${ }^{252}$ the Court of Appeals held that the trial court did not abuse its discretion when it imposed a probation condition prohibiting the defendant — convicted by a jury of battery resulting in bodily injury - from

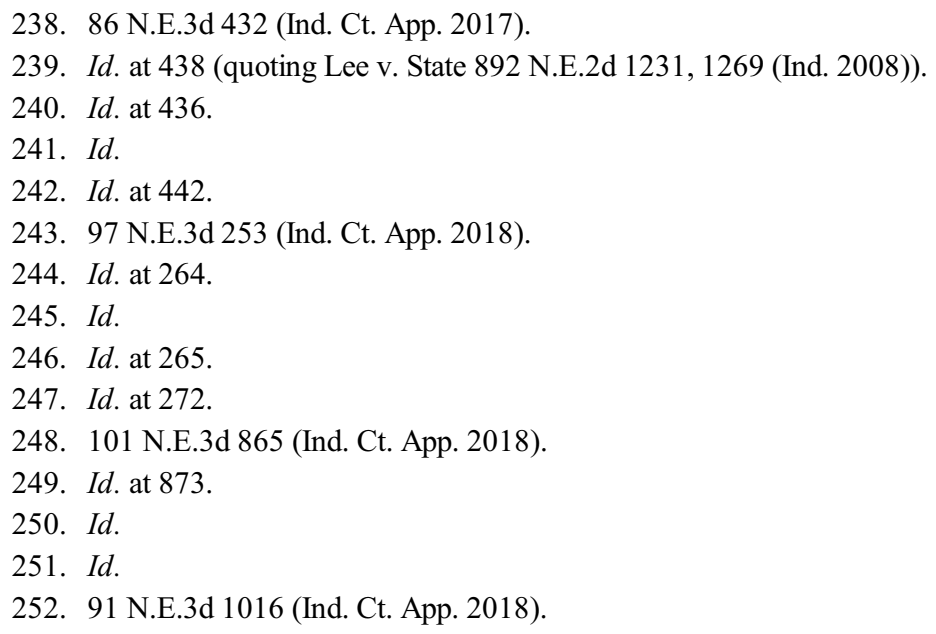


possessing firearms during his one-year probationary period. ${ }^{253}$ Under a rational basis review, the court assesses whether the restriction was a valid exercise of the "police power to promote health, safety, comfort, morals, and the public welfare. ${ }^{254}$ Provided the restriction survives that rational basis review, the court then reviews whether the restriction "materially burdens" a "core value." 255

The Court of Appeals found that the firearm restriction survived rational basis review because restricting a person convicted of a violent crime was "rationally calculated to advance the legitimate government interest in keeping firearms out of the hands of those who have shown a propensity for violence by committing a violent crime." ${ }^{256}$ The restriction did not impose a "substantial obstacle" on the defendant's right to bear arms for self-defense because it was a temporary oneyear period. ${ }^{257}$ And even if this was a substantial burden on the defendant, his claim would still fail because his possession of firearms during his probation would threaten to inflict "particularized harm" on others. ${ }^{258}$ Given his propensity for violence, law enforcement had a legitimate need to protect the probation officers who would be visiting him. ${ }^{259}$

\section{DiSTRIBUTION OF POWERS (ARTICLE 3, § 1)}

In Calvin v. State, ${ }^{260}$ Chief Justice Rush, writing for the majority, found the absurdity doctrine not applicable to the application of the habitual-offenders statute to defendant's non-Indiana convictions. ${ }^{261}$ This matter arises from defendant's sentence for a level 4 felony burglary conviction and habitual-offender enhancement. ${ }^{262}$ The defendant was charged with, and convicted of, a level 4 felony burglary, and his sentence was enhanced based on the defendant classifying as a habitual offender based on two prior Illinois class 1 felony burglary convictions. ${ }^{263}$ The defendant challenged the enhancement of his sentence because his prior convictions were Illinois felonies, which are treated as level 6 felonies by the Indiana habitual-offender statute, and two level 6 felonies cannot support a habitual-offender enhancement. ${ }^{264}$ The Court of Appeals, finding the absurdity doctrine applied, affirmed the defendant's enhanced sentence finding his non-Indiana convictions should be treated as level

253. Id. at 1029.

254. Id. at 1027 (citing Redington v. State, 992 N.E. 2 d 823 (Ind. Ct. App. 2013)).

255. Id.

256. Id. The Court had already found that the restriction survived Second Amendment intermediate scrutiny.

257. Id. at 1028 .

258. Id.

259. Id. at 1029.

260. 87 N.E.3d 474 (Ind. 2017).

261. Id. at 479 .

262. Id. at 475.

263. Id.

264. Id. 
4 felonies instead of level 6 felonies. ${ }^{265}$

Even though the Supreme Court noted that the habitual offender statute treating all non-Indiana convictions as level 6 felonies is "peculiar" with the potential to lead to "incongruous results - especially when the non-Indiana felonies are grievous," the Supreme Court declined to extend the absurdity doctrine to the habitual-offender statutes and reversed the defendant's habitual-offender enhancement. ${ }^{266}$ The Supreme Court found that the statute's plain meaning was clear and had applied for nearly thirty years and that treating the defendant's non-Indiana felonies as level 4 felonies would be more of a sweeping policy decision suited for the legislature rather than the judiciary. ${ }^{267}$ "Regardless of whether we can discern the legislature's reasons for writing the habitual-offender statutes as it did, we cannot rewrite - and certainly cannot broaden - them through the absurdity doctrine. Any change must instead fall to the legislature's corrective pen."268

In Justice Massa's dissent, he found the separation of powers should not prevent the Court from avoiding "an outcome that is, if not absurd, at least 'peculiar' as the Court mildly puts it." ${ }^{269} \mathrm{He}$ found that prior applications of the habitual-offender statutes were not as severe as defendant's crimes and the legislature's "imprecision" in drafting the statutes "does not dictate this windfall for serious habitual offenders who built their records victimizing people in other states. ${ }^{270}$ The defendant's crimes should not be treated as less severe just because they were committed in a different state.

\section{ARTICLE 7, § 4/6 - JURISDICTION OF APPELLATE COURTS}

In Taylor v. State, ${ }^{271}$ the Indiana Supreme Court reduced the life without parole sentence for a seventeen-year-old convicted of murder to eighty years pursuant to the Supreme Court's authority under Article 7, Section 4 of the Indiana Constitution. A jury convicted the defendant of murder and sentenced him to life without parole for murdering another teenager with a firearm. Among other arguments, the defendant argued that sentencing him to life without parole was inappropriate and should be reduced under Article 7, Section 4 of the Indiana Constitution.

Article 7, Section 4 permits the Court to "revise sentences that are inappropriate in light of the nature of the offense and the character of the offender." ${ }^{272}$ When considering whether to revise sentences, the Court considers the offenses and character of the defendant.

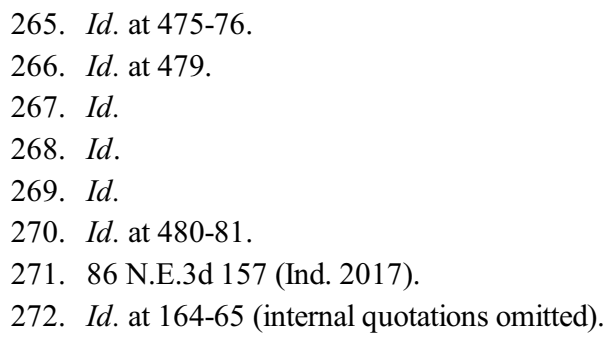


As a preliminary matter, the Court found that the life without parole sentence was lawful, and that the trial court was very meticulous in weighing the evidence. However, even though lawful, life without parole "is the harshest punishment the Constitution permits against any child." ${ }^{273}$ In fact, the punishment is so severe, that only four juveniles have ever received a sentence of life without parole. Of those four cases, three did not challenge the appropriateness of their sentences, and so the Indiana Supreme Court only has upheld the life without parole sentence for a juvenile once where the juvenile used his bare hands to murder his ten-year-old brother.

The Supreme Court did not find defendant's case to be such a grievous circumstance warranting life without parole. The Supreme Court considered mitigating factors, such as defendant's age, bad influences, growing up fatherless, and the recent gang activity and drug and alcohol abuse in defendant's neighborhood. Accordingly, the Supreme Court found that defendant's actions "do not warrant making him Indiana's fifth juvenile sentenced to a guaranteed death in prison" and reduced his sentence to eighty years. ${ }^{274}$

In In re Young, ${ }^{275}$ the Indiana Supreme Court exercised its original jurisdiction under Article 7, Section 4 of the Indiana Constitution and Indiana Admission and Discipline Rule 25 to suspend a circuit court judge for misconduct. This matter arises from a dispute between a county clerk and a circuit court judge regarding cuts to the clerk's budget. When a county council announced cuts to the clerk's budget, the clerk was upset and concerned with the workload and limited staff. In an effort to ease the clerk's burden, the judge transferred certain open files to his office. This upset the clerk, and she referred to the judge by obscene names to her office staff and the county council. However, she did not make any specific threats to destroy court records or refuse to fulfill her job responsibilities. After hearing about the clerk's behavior, the judge ordered the clerk to his office for a meeting. During this heated meeting, the clerk and judge argued, and the clerk walked away.

The judge then brought a hearing, sua sponte, to enjoin the clerk from the courthouse, and found the clerk unfit to fulfill her duties. The clerk did not receive notice of and was not present at this hearing. The judge then issued a temporary restraining order enjoining the clerk from entering the courthouse. After six days, the judge dissolved the temporary restraining order upon advice from counsel for the Indiana Commission on Judicial Qualifications.

Special Masters were appointed to hear evidence against the judge due to him presiding over the hearing for a temporary restraining order in which he was the requestor. After considering the evidence, the Special Masters recommended that the judge be suspended for six days (the same duration of the temporary restraining order) without pay and be ordered to pay the costs of the proceedings.

Recognizing the importance of deterring similar misconduct of judges and the severity of a suspension without pay, the Supreme Court adopted the Special

273. Id. at 165 .

274. See id.

275. 92 N.E.3d 628 (Ind. 2018). 
Masters' findings and recommendations. "The purpose of judicial discipline is not primarily to punish a judge, but rather to preserve the integrity of and public confidence in the judicial system and, when necessary, safeguard the bench and public from those who are unfit." ${ }^{276}$

276. Id. at 634 (quoting In re Hawkins, 902 N.E.2d 231, 244 (Ind. 2009)). 